\title{
Pharmacological therapy and blood pressure control in primary health care sites in China: data from 254,848 hypertensive patients
}

This article was published in the following Dove Press journal:

Clinical Epidemiology

Lei Hou,' Xiaorong Chen,' Bo Chen,' Longjian Liu, ${ }^{2}$ Xiaohui Sun, ${ }^{1,3}$ Yuewei Zou, ${ }^{4}$ Hongjian Liu, ${ }^{5}$ Hui Guo, ${ }^{6}$ Jian Zhang, ${ }^{7}$ Jixiang $\mathrm{Ma}^{\mathrm{I}}$

'National Center for Chronic and Noncommunicable Disease Control and Prevention, Chinese Center for Disease Control and Prevention, Beijing, 100050, China ${ }^{2}$ Department of Epidemiology and Biostatistics Drexel University Dornsife School of Public Health, Philadelphia, PA, 19104, USA; ${ }^{3}$ Qingdao Center for Disease Control and Prevention, Qingdao, 266033, China; ${ }^{4}$ Rushan Center for Disease Control and Prevention, Rushan, 264500, China; ${ }^{5}$ Taixing Center for Disease Control and Prevention, Taixing, 225400, China; ${ }^{6}$ Xiangtan Center for Disease Control and Prevention, Xiangtan, 4III00, China; ${ }^{7}$ Wuhou Center for Disease Control and Prevention, Wuhou, 61004I, China

\section{Video abstract}

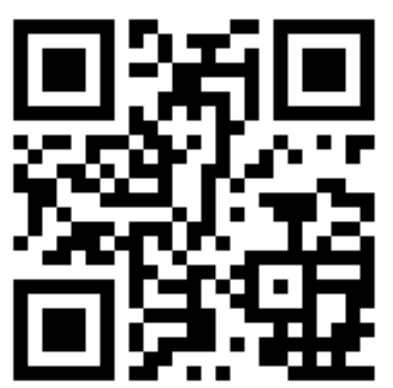

Point your SmartPhone at the code above. If you have a QR code reader the video abstract will appear. Or use: http://youtu.be/olNq17Xolrs

Correspondence: Jixiang Ma National Center for Chronic and Noncommunicable Disease Control and Prevention, Chinese Center for Disease Control and Prevention, Number 27 Nanwei Road, Xicheng District, Beijing, 100050, China

$\mathrm{Tel}+861083133681$

Fax +86106304 2350

Email majixiang@ncncd.chinacdc.cn
Background: Studies on pharmacological therapy and blood pressure (BP) control in primary health care sites of China are limited. We aimed to investigate drug use and compliance as well as compare BP control between pharmacological therapies for lowering BP in hypertensive population serviced by these sites.

Methods: This is a 1-year cohort study using electronic health care records from the National Primary Public Health Services of China. For patients with antihypertensive drugs at the first follow-up, we defined compliance with treatment as a continued treatment with the same specified class of agents at next three follow-ups. In those with compliance, BP control was defined as systolic $\mathrm{BP}<140 \mathrm{mmHg}$ and diastolic $\mathrm{BP}<90 \mathrm{mmHg}$ in four follow-ups within 1 year.

Results: Primary health care sites of four areas managed 254,848 hypertensive patients aged $\geq 35$ years. At the first follow-up, $50.2 \%$ of the patients took medicines for lowering BP. In those, calcium channel antagonist monotherapy was the most common medicine in urban areas $(57.1 \%$ vs $15.6 \%$ in rural areas, $P<0.001$ ); however, the most common one was single-pill combinations including diuretics and non-first-line drugs in rural areas $(34.4 \% \mathrm{vs} 10.7 \%$ in urban areas, $P<0.001$ ). Compliance was $79.9 \%$ and $53.2 \%$ for single- and multiple-pill combinations in first-line drugs; this rate was $69.5 \%$ and $45.0 \%$ in regimens combined with non-first-line drugs, respectively. Compared with calcium channel antagonists, diuretics monotherapy increased the overall BP control by $11 \%$ (risk ratio, $1.11 ; 95 \%$ confidence interval, 1.08 to 1.13 ), but it was used in few patients (3.3\%); first-line multiple-pill combinations significantly decreased BP control by $20 \%$ to $28 \%$ in three less urbanized areas, but a similar BP control was achieved in the highly urbanized area.

Conclusion: Our study indicated that drug use such as diuretics could be strengthened in primary health care sites and combined therapy may be improved particularly in less urbanized areas.

Keywords: hypertension, drugs, primary health care, public health

\section{Introduction}

Most randomized controlled trials (RCTs) have affirmed that the main benefits of antihypertensive treatment are owing to lowering blood pressure (BP) and are largely independent of drugs employed. ${ }^{1,2}$ Guidelines underline that most patients require combined therapy of two or more drugs to achieve a better BP control compared with monotherapy. ${ }^{2}$ However, these evidences on the efficacy of antihypertensive drugs are overwhelmingly based on a controlled environment of experienced and researchintensive sites such as tertiary hospitals. Culture, resources, and capacity of primary health care practice in a variety of community settings challenge a translation of evidence from "efficacy" in RCTs into "effectiveness" in the real world. ${ }^{3}$ Especially 
in China, tertiary hospitals own most health care resources, but they account for only $0.2 \%$ of the total medical institutions as well as provide only $17.9 \%$ of the outpatient clinic services; ${ }^{4}$ thus, the Chinese health reform strengthens the role of primary health care by providing free primary health care services, including hypertension management, for local residents with the support of the annually central budget. ${ }^{5}$ Prevalence of hypertension in Chinese adults has increased from $18.8 \%$ in 2002 to $27.8 \%$ in $2013-2014$, equivalent to up to 292 million patients..$^{6,7}$ The National Primary Public Health Services of China (NPPHS) has managed 86 million hypertensive patients in 2015. Prospectively, this number of hypertensive patients involved will increase to 110 million in 2025.

However, studies on drug use and compliance as well as comparing BP control between pharmacological therapies mono or combined - for lowering BP in hypertensive population serviced by primary health care sites are limited. For this aim, we designed and conducted a 1-year cohort study.

\section{Methods}

\section{Data sources and patients}

We selected Rushan county-level city in Shandong province, Taixing county-level city in Jiangsu province, Yuhu district in Hunan province, and Wuhou district in Sichuan province as study base. The rural areas of Rushan and Taixing own population size similar to the urban areas of Yuhu and Taixing. In these areas, Rushan and Taixing represent typical rural areas with an urbanization rate of $27.4 \%$ and $30.7 \%$, respectively; Yuhu represents a typical urban area without the whole of urbanization $(87.0 \%)$; and Wuhou is a totally urbanized area $(100 \%)$. Table 1 shows that primary health care sites provided more shares of health care services in less urbanized areas than that in urbanized areas. We used databases, which include all patients $(258,774)$ managed by all primary health care sites of these areas since the launch of the health care reform plan in 2009 , on the information platform of the NPPHS. We accessed patients' electronic health care files since July 1, 2009, and extracted the initial information of patients and follow-up records from July 1, 2013, through June 30, 2014.

Chinese hypertension guidelines define hypertension diagnosis as systolic BP (SBP) $\geq 140 \mathrm{mmHg}$ and diastolic BP (DBP) $\geq 90 \mathrm{mmHg}$ in three different days for untreated individuals. The NPPHS provides a hypertension screening for residents aged $\geq 35$ years. Individuals with $\mathrm{SBP} \geq 140$ $\mathrm{mmHg}$ and DBP $\geq 90 \mathrm{mmHg}$ in initial screenings will be followed or referred for a definite diagnosis. Under the NPPHS
Table I Characteristics of four county-level and district areas selected

\begin{tabular}{lllll}
\hline Characteristics & Rushan & Taixing & Yuhu & Wuhou \\
\hline Resident population (million) & 0.59 & 1.08 & 0.57 & 1.08 \\
Urbanization rate (\%) & 27.4 & 30.7 & 87.0 & 100.0 \\
Number of medical institutes & & & & \\
$\quad$ Tertiary hospitals & $\mathrm{I}$ & $\mathrm{I}$ & 2 & 8 \\
$\quad$ Secondary hospitals & $\mathrm{I}$ & 4 & 4 & 12 \\
Primary health care sites $^{\mathrm{a}}$ & 490 & 420 & 450 & 70 \\
\hline
\end{tabular}

Note: aPrimary hospitals, health centers, and clinics included.

policy, all patients with a definite diagnosis in screenings and a stable condition in secondary or tertiary hospitals should be managed in primary health care sites. Therefore, we defined our study population as patients aged $\geq 35$ years with a diagnosis of hypertension served by primary health care sites. ${ }^{8}$ We performed this study under an approval from the National Center for Chronic and Noncommunicable Disease Control and Prevention Chinese Center for Disease Control and Prevention. The data accessed from the NPPHS were de-identified. It was recognized that the right and the welfare of the subjects in this study were adequately protected; the potential benefits from this study and the potential risks to subjects were within a reasonable range.

\section{Measurements and definitions}

According to the NPPHS policy, trained general practitioners measured with an appropriate arm cuff and a qualified mercury column sphygmomanometer ( $<5 \%$ from electronic sphygmomanometers) on the upper arm and recorded BP values after a resting period in the seated position with back supported, arm resting at heart level, and feet on the floor. Meanwhile, they filled out electronic health care files including height, weight, history of diseases (eg, diabetes), $\mathrm{BP}$, and drug use. We defined invalid $\mathrm{BP}$ values as $\mathrm{SBP}>260$ $\mathrm{mmHg}$ or SBP $<70 \mathrm{mmHg}, \mathrm{DBP}>150 \mathrm{mmHg}$ or DBP $<40$ $\mathrm{mmHg}$, and pulse pressure $>150 \mathrm{mmHg}$ or pulse pressure $<20 \mathrm{mmHg} .{ }^{9}$ All patients included in our analysis had valid baseline BPs defined as the mean of two readings. ${ }^{7,8}$ We also defined stages $1-3$ of hypertension and controlled hypertension at baseline as SBP $=140-159 \mathrm{mmHg}$ and/or DBP $=90-99$ $\mathrm{mmHg}, \mathrm{SBP}=160-179 \mathrm{mmHg}$ and/or DBP $=100-109$ $\mathrm{mmHg}, \mathrm{SBP} \geq 180 \mathrm{mmHg}$ and/or DBP $\geq 110 \mathrm{mmHg}$, and SBP $<140 \mathrm{mmHg}$ and DBP $<90 \mathrm{mmHg}$, respectively. ${ }^{7}$ The NPPHS policy required four free follow-ups with qualified BP measurements per year after an establishment of hypertension-related health care files. ${ }^{8}$ For patients with five or more follow-ups, we kept the first two and the last two ones under the calculation of compliance. Our analysis excluded the 
middle follow-up records near the year end, likely affected by an annual assessment. Therefore, each patient had zero to four follow-ups. For patients with antihypertensive medication at the first follow-up, compliance with treatment was defined as a continued treatment with the same specified class of antihypertensive agents at next three follow-ups, ie, medication possession ratio (MPR) - the ratio of total days of medication supplied to total days in a period of time - equals to 1.0. ${ }^{10}$ In those with compliance, BP control was defined as SBP $<140 \mathrm{mmHg}$ and DBP $<90 \mathrm{mmHg}$ of four follow-ups within 1 year. ${ }^{7}$ Current Chinese guidelines recommended calcium channel antagonists (CCBs), diuretics, beta-blockers (BBs), angiotensin-converting enzyme (ACE) inhibitors (ACEIs), and angiotensin receptor blockers (ARBs) as the first-line antihypertensive drugs; the non-first-line drugs in this study mainly included reserpine, dibazole, alpha-blockers (ABs), and traditional Chinese medicine (TCM) such as luobuma (Apocynum venetum L) and Ginkgo biloba. In China, a first-line drug is commonly combined with non-first-line components, but Chinese guidelines do not oppose this use; this prescription was defined as first- and non-first-line drugs such as a fixed-dose single-pill combination drug consisting of hydrochlorothiazide as well as reserpine, potassium chloride, dihydralazine sulfate, and promethazine.

\section{Statistical analyses}

We used risk ratio (RR) with $95 \%$ confidence intervals (CIs) to compare the rate of BP control between drugs, based on robust Poisson method-based models and adjusted for confounders such as gender, age, areas, baseline SBP, body mass index, and diabetic history. In order to correct intraclass correlation, such models combined areas as repeat measurements. ${ }^{11}$ A paired $t$-test was employed in comparisons before and after treatment. All analyses employed SAS version 9.2 (SAS Institute, Cary, NC, USA). All $P$-values were two-sided except $P$ trend tests based on the robust Poisson method, in which we used one-sided $P$-values, and a $P$-value $<0.05$ was statistically significant.

\section{Results}

Due to missing or invalid information at baseline of variables such as gender, age, and BP, 3,926 (1.5\%) individuals were excluded. The final database included 254,848 hypertensive patients. Table 2 shows the characteristics of baseline population. In total, $44.4 \%$ was male; the mean age was $66.1 \pm 11.4$ years. Proportions of managed patients in the local residents and BP levels were likely higher in rural areas, compared with urban areas. Regardless of geographic variations, $>65 \%$ of the managed patients achieved the policy requirement of four follow-ups within 1 year.

We found 127,871 hypertensive patients (50.2\%) with any antihypertensive drug at the first follow-up (Table 3). Of whom, patients with first-line antihypertensive drugs accounted for $64.9 \%$; this proportion was higher in urban areas compared with rural areas ( $85.3 \%$ vs $55.8 \%, P<0.001)$. Patients with CCBs, ACEIs, diuretics, ARBs, and BBs in monotherapy accounted for $28.8 \%, 18.3 \%, 3.3 \%, 1.7 \%$, and $1.2 \%$ of treated patients, respectively. CCB monotherapy was the most common medication in urban areas $(57.1 \%$ vs $15.6 \%$ in rural areas, $P<0.001)$; in rural areas, however, the most common one was single-pill combinations including first-line drugs - diuretics were factually combined into all pills - and non-first-line drugs (34.4\% vs $10.7 \%$ in urban areas, $P<0.001)$. Despite a less use of diuretics monotherapy,

Table 2 Characteristics of hypertensive populations included

\begin{tabular}{|c|c|c|c|c|c|}
\hline \multirow[t]{2}{*}{ Characteristics } & \multicolumn{4}{|c|}{ County-level and district areas } & \multirow[t]{2}{*}{ Total } \\
\hline & Rushan & Taixing & Yuhu & Wuhou & \\
\hline Number of hypertensive patients managed & 48,628 & 113,662 & 45,360 & 47,198 & 254,848 \\
\hline Age (years) & $64.9 \pm 10.7$ & $66.9 \pm 12.0$ & $67.6 \pm 10.4$ & $64.3 \pm 11.5$ & $66.1 \pm 11.4$ \\
\hline Male (\%) & 39.2 & 46.2 & 43.7 & 46.0 & 44.4 \\
\hline Baseline SBP (mmHg) & $155.5 \pm 20.3$ & $139.0 \pm 17.2$ & $132.8 \pm 17.4$ & $127.9 \pm 9.0$ & $139.0 \pm 19.0$ \\
\hline Baseline DBP (mmHg) & $92.7 \pm 11.3$ & $85.0 \pm 10.2$ & $81.2 \pm 10.0$ & $76.1 \pm 6.8$ & $84.2 \pm 11.2$ \\
\hline Controlled hypertension (\%) & 12.5 & 39.2 & 65.4 & 91.1 & 48.4 \\
\hline Stage I hypertension (\%) & 33.0 & 40.9 & 22.7 & 7.2 & 29.9 \\
\hline Stage 2 hypertension (\%) & 34.3 & 15.6 & 9.0 & 1.5 & 15.4 \\
\hline Stage 3 hypertension (\%) & 20.2 & 4.3 & 2.8 & 0.3 & 6.3 \\
\hline Antihypertensive medications (\%) ${ }^{\mathrm{a}}$ & 66.4 & 48.5 & 74.3 & 14.3 & 50.2 \\
\hline Previously diagnosed diabetes (\%) & 9.1 & $\mathrm{II} .2$ & 8.9 & 28.5 & 13.6 \\
\hline Body mass index $\left(\mathrm{kg} / \mathrm{m}^{2}\right)$ & $25.7 \pm 3.3$ & $23.8 \pm 3.2$ & $23.7 \pm 3.1$ & $23.3 \pm 2.7$ & $24.1 \pm 3.2$ \\
\hline$\geq 4$ follow-ups (\%) & 77.3 & 68.6 & 78.4 & 80.4 & 74.2 \\
\hline
\end{tabular}

Notes: any use of antihypertensive drugs observed at the first follow-up.

Abbreviations: DBP, diastolic blood pressure; SBP, systolic blood pressure. 
patients frequently took diuretics in compound with other antihypertensive components, such as other first-line antihypertensives (ACEIs or ARBs) and non-first-line antihypertensives (reserpine, dibazole, or TCMs); this accumulated a large population (41.1\%) accessing diuretics in the form of diuretics only $(3.3 \%)$, single-pill combination $(5.6 \%$ for first-line drugs plus $26.9 \%$ for non-first-line drugs), and multiple-pill combination (5.2\%).

About 104,333 (81.6\%) patients with antihypertensive medications at the first follow-up persisted in treatments at the next three follow-ups. Compliance rates varied from $58.5 \%$ to $73.5 \%$ for first-line monotherapies. For single- and multiple-pill combinations in first-line drugs, compliance was $79.9 \%$ and $53.2 \%$; for regimens combined with non-first-line drugs, this rate was $69.5 \%$ and $45.0 \%$, respectively. In those with compliance, an overall rate of BP control was $44.2 \%$ and this rate was $50.4 \%, 38.2 \%$, and $48.8 \%$ for first-line, first- and non-first-line, and non-first-line drugs, respectively. Table 4 shows a rate of BP control of main drug uses. Patients in more urbanized areas retained a better BP control for each drug use.
Considering difference of baseline BPs in patients between areas, we showed mean baseline BP levels stratified according to drug class and mean decreases after treatment. As shown in Table 5, populations with higher baseline BP levels had more BP decreases for each drug in Rushan, Taixing, and Yuhu and for the Wuhou population with a low BP level at baseline, this fair BP level retained in each drug group. Specially, in this population with compliance, rural individuals with higher baseline BPs had more benefits on BP decreases, compared with urban individuals. We compared baseline characteristics in people with different drugs and BP control between main drug uses (Table S1; Figure 1). Due to a popular use of CCBs, we included patients with $\mathrm{CCB}$ monotherapy as the reference group. Compared with $\mathrm{CCB}$ monotherapy, $\mathrm{BBs}$ as well as ACEIs and ARBs showed a similar BP control after the adjustment for confounders, regardless of areas; diuretics monotherapy increased an overall BP control by $11 \%$ (RR, $1.11 ; 95 \%$ CI, 1.08-1.13) despite a less use. Interestingly, first-line multiple-pill combinations generally decreased BP control by $26 \%(\mathrm{RR}, 0.74 ; 95 \% \mathrm{CI}, 0.70-0.79)$ in three less

Table 3 Antihypertensive drugs at the first follow-up and compliance with treatment in hypertensive populations

\begin{tabular}{|c|c|c|c|c|c|c|c|c|c|c|}
\hline & \multicolumn{5}{|c|}{$\begin{array}{l}\text { Number (\%) of patients with specific drug classes at } \\
\text { the first follow-up }\end{array}$} & \multicolumn{5}{|c|}{$\begin{array}{l}\text { Number }\left(\%^{a}\right) \text { of patients with the same specified } \\
\text { class of drugs at next three follow-ups }\end{array}$} \\
\hline & Rushan & Taixing & Yuhu & Wuhou & Total & Rushan & Taixing & Yuhu & Wuhou & Total \\
\hline Any first-line drugs & $\begin{array}{l}19,715 \\
(61.1)\end{array}$ & $\begin{array}{l}28,737 \\
(52.1)\end{array}$ & $\begin{array}{l}28,177 \\
(83.6)\end{array}$ & $\begin{array}{l}6,295 \\
(93.0)\end{array}$ & $\begin{array}{l}82,924 \\
(64.9)\end{array}$ & $\begin{array}{l}12,099 \\
(61.4)\end{array}$ & $\begin{array}{l}22,800 \\
(79.3)\end{array}$ & $\begin{array}{l}24,052 \\
(85.4)\end{array}$ & $\begin{array}{l}4,997 \\
(79.4)\end{array}$ & $\begin{array}{l}63,948 \\
(77.1)\end{array}$ \\
\hline CCB only & $\begin{array}{l}6,730 \\
(20.9)\end{array}$ & $\begin{array}{l}6,932 \\
(12.6)\end{array}$ & $\begin{array}{l}19,37 \mid \\
(57.5)\end{array}$ & $\begin{array}{l}3,746 \\
(55.4)\end{array}$ & $\begin{array}{l}36,779 \\
(28.8)\end{array}$ & $\begin{array}{l}2,588 \\
(38.5)\end{array}$ & $\begin{array}{l}5,257 \\
(75.8)\end{array}$ & $\begin{array}{l}16,243 \\
(83.9)\end{array}$ & $\begin{array}{l}2,928 \\
(78.2)\end{array}$ & $\begin{array}{l}27,016 \\
(73.5)\end{array}$ \\
\hline Diuretics only & $\begin{array}{l}2,064 \\
(6.4)\end{array}$ & $\begin{array}{l}177 \\
(0.3)\end{array}$ & $\begin{array}{l}1,849 \\
(5.5)\end{array}$ & $\begin{array}{l}170 \\
(2.5)\end{array}$ & $\begin{array}{l}4,260 \\
(3.3)\end{array}$ & $\begin{array}{l}725 \\
(35.1)\end{array}$ & $\begin{array}{l}132 \\
(74.6)\end{array}$ & $\begin{array}{l}1,504 \\
(81.3)\end{array}$ & $\begin{array}{l}132 \\
(77.7)\end{array}$ & $\begin{array}{l}2,493 \\
(58.5)\end{array}$ \\
\hline BB only & $\begin{array}{l}443 \\
(1.4)\end{array}$ & $\begin{array}{l}233 \\
(0.4)\end{array}$ & $\begin{array}{l}649 \\
(1.9)\end{array}$ & $\begin{array}{l}243 \\
(3.6)\end{array}$ & $\begin{array}{l}1,568 \\
(1.2)\end{array}$ & $\begin{array}{l}145 \\
(32.7)\end{array}$ & $\begin{array}{l}175 \\
(75.1)\end{array}$ & $\begin{array}{l}567 \\
(87.4)\end{array}$ & $\begin{array}{l}173 \\
(71.2)\end{array}$ & $\begin{array}{l}1,060 \\
(67.6)\end{array}$ \\
\hline ACEI only & $\begin{array}{l}6,109 \\
(18.9)\end{array}$ & $\begin{array}{l}|2,72| \\
(23.1)\end{array}$ & $\begin{array}{l}3,768 \\
(11.2)\end{array}$ & $\begin{array}{l}801 \\
(11.8)\end{array}$ & $\begin{array}{l}23,399 \\
(18.3)\end{array}$ & $\begin{array}{l}1,613 \\
(26.4)\end{array}$ & $\begin{array}{l}9,735 \\
(76.5)\end{array}$ & $\begin{array}{l}3,221 \\
(85.5)\end{array}$ & $\begin{array}{l}615 \\
(76.8)\end{array}$ & $\begin{array}{l}15,184 \\
(64.9)\end{array}$ \\
\hline ARB only & $\begin{array}{l}804 \\
(2.5)\end{array}$ & $\begin{array}{l}299 \\
(0.5)\end{array}$ & $\begin{array}{l}777 \\
(2.3)\end{array}$ & $\begin{array}{l}315 \\
(4.7)\end{array}$ & $\begin{array}{l}2,195 \\
(1.7)\end{array}$ & $\begin{array}{l}388 \\
(48.3)\end{array}$ & $\begin{array}{l}231 \\
(77.3)\end{array}$ & $\begin{array}{l}656 \\
(84.4)\end{array}$ & $\begin{array}{l}217 \\
(68.9)\end{array}$ & $\begin{array}{l}1,492 \\
(68.0)\end{array}$ \\
\hline $\begin{array}{l}\text { Single-pill } \\
\text { combination }\end{array}$ & 0 & $\begin{array}{l}5,859 \\
(10.6)\end{array}$ & $\begin{array}{l}1,252 \\
(3.7)\end{array}$ & $\begin{array}{l}3 \\
(0.0)\end{array}$ & $\begin{array}{l}7,114 \\
(5.6)\end{array}$ & - & $\begin{array}{l}4,596 \\
(78.4)\end{array}$ & $\begin{array}{l}1,074 \\
(85.8)\end{array}$ & $\begin{array}{l}3 \\
(100.0)\end{array}$ & $\begin{array}{l}5,673 \\
(79.7)\end{array}$ \\
\hline $\begin{array}{l}\text { Multiple-pill } \\
\text { combination }\end{array}$ & $\begin{array}{l}3,565 \\
(I 1.1)\end{array}$ & $\begin{array}{l}2,516 \\
(4.6)\end{array}$ & $\begin{array}{l}511 \\
(1.5)\end{array}$ & $\begin{array}{l}1,017 \\
(15.0)\end{array}$ & $\begin{array}{l}7,609 \\
(6.0)\end{array}$ & $\begin{array}{l}1,027 \\
(28.8)\end{array}$ & $\begin{array}{l}2,000 \\
(79.5)\end{array}$ & $\begin{array}{l}350 \\
(68.5)\end{array}$ & $\begin{array}{l}674 \\
(66.3)\end{array}$ & $\begin{array}{l}4,051 \\
(53.2)\end{array}$ \\
\hline $\begin{array}{l}\text { Any first- and non- } \\
\text { first-line drugs }\end{array}$ & $\begin{array}{l}11,028 \\
(34.2)\end{array}$ & $\begin{array}{l}24,516 \\
(44.5)\end{array}$ & $\begin{array}{l}4,296 \\
(12.8)\end{array}$ & $\begin{array}{l}338 \\
(5.0)\end{array}$ & $\begin{array}{l}40,178 \\
(31.4)\end{array}$ & $\begin{array}{l}3,946 \\
(35.8)\end{array}$ & $\begin{array}{l}19,954 \\
(81.4)\end{array}$ & $\begin{array}{l}3,508 \\
(81.7)\end{array}$ & $\begin{array}{l}253 \\
(74.9)\end{array}$ & $\begin{array}{l}27,661 \\
(68.9)\end{array}$ \\
\hline $\begin{array}{l}\text { Single-pill } \\
\text { combination }\end{array}$ & $\begin{array}{l}7,973 \\
(24.7)\end{array}$ & $\begin{array}{l}22,122 \\
(40.1)\end{array}$ & $\begin{array}{l}4,039 \\
(12.0)\end{array}$ & $\begin{array}{l}299 \\
(4.4)\end{array}$ & $\begin{array}{l}34,433 \\
(26.9)\end{array}$ & $\begin{array}{l}2,362 \\
(29.6)\end{array}$ & $\begin{array}{l}17,849 \\
(80.7)\end{array}$ & $\begin{array}{l}4,372 \\
(82.7)\end{array}$ & $\begin{array}{l}225 \\
(75.3)\end{array}$ & $\begin{array}{l}24,808 \\
(69.5)\end{array}$ \\
\hline $\begin{array}{l}\text { Multiple-pill } \\
\text { combination }\end{array}$ & $\begin{array}{l}3,055 \\
(9.5)\end{array}$ & $\begin{array}{l}2,394 \\
(4.3)\end{array}$ & $\begin{array}{l}257 \\
(0.8)\end{array}$ & $\begin{array}{l}39 \\
(0.6)\end{array}$ & $\begin{array}{l}5,745 \\
(4.5)\end{array}$ & $\begin{array}{l}467 \\
(15.3)\end{array}$ & $\begin{array}{l}1,915 \\
(80.0)\end{array}$ & $\begin{array}{l}176 \\
(68.5)\end{array}$ & $\begin{array}{l}28 \\
(71.8)\end{array}$ & $\begin{array}{l}2,586 \\
(45.0)\end{array}$ \\
\hline $\begin{array}{l}\text { Any non-first-line } \\
\text { drugs }\end{array}$ & $\begin{array}{l}1,530 \\
(4.7)\end{array}$ & $\begin{array}{l}1,874 \\
(3.4)\end{array}$ & $\begin{array}{l}1,232 \\
(3.7)\end{array}$ & $\begin{array}{l}133 \\
(2.0)\end{array}$ & $\begin{array}{l}4,769 \\
(3.7)\end{array}$ & $\begin{array}{l}329 \\
(21.5)\end{array}$ & $\begin{array}{l}1,417 \\
(75.6)\end{array}$ & $\begin{array}{l}1,021 \\
(82.9)\end{array}$ & $\begin{array}{l}104 \\
(78.2)\end{array}$ & $\begin{array}{l}2,871 \\
(60.2)\end{array}$ \\
\hline Total & $\begin{array}{l}32,273 \\
(100.0)\end{array}$ & $\begin{array}{l}55,127 \\
(100.0)\end{array}$ & $\begin{array}{l}33,705 \\
(100.0)\end{array}$ & $\begin{array}{l}6,766 \\
(100.0)\end{array}$ & $\begin{array}{l}|27,87| \\
(100.0)\end{array}$ & $\begin{array}{l}24,120 \\
(74.7)\end{array}$ & $\begin{array}{l}45,681 \\
(82.9)\end{array}$ & $\begin{array}{l}29,157 \\
(86.5)\end{array}$ & $\begin{array}{l}5,375 \\
(79.4)\end{array}$ & $\begin{array}{l}104,333 \\
(81.6)\end{array}$ \\
\hline
\end{tabular}

Note: ${ }^{a}$ Denominators are number of patients with specific drugs at the first follow-up.

Abbreviations: $\mathrm{ACEl}$, angiotensin-converting enzyme inhibitor; $\mathrm{ARB}$, angiotensin receptor blocker; $\mathrm{BB}$, beta-blocker; $\mathrm{CCB}$, calcium channel antagonist. 


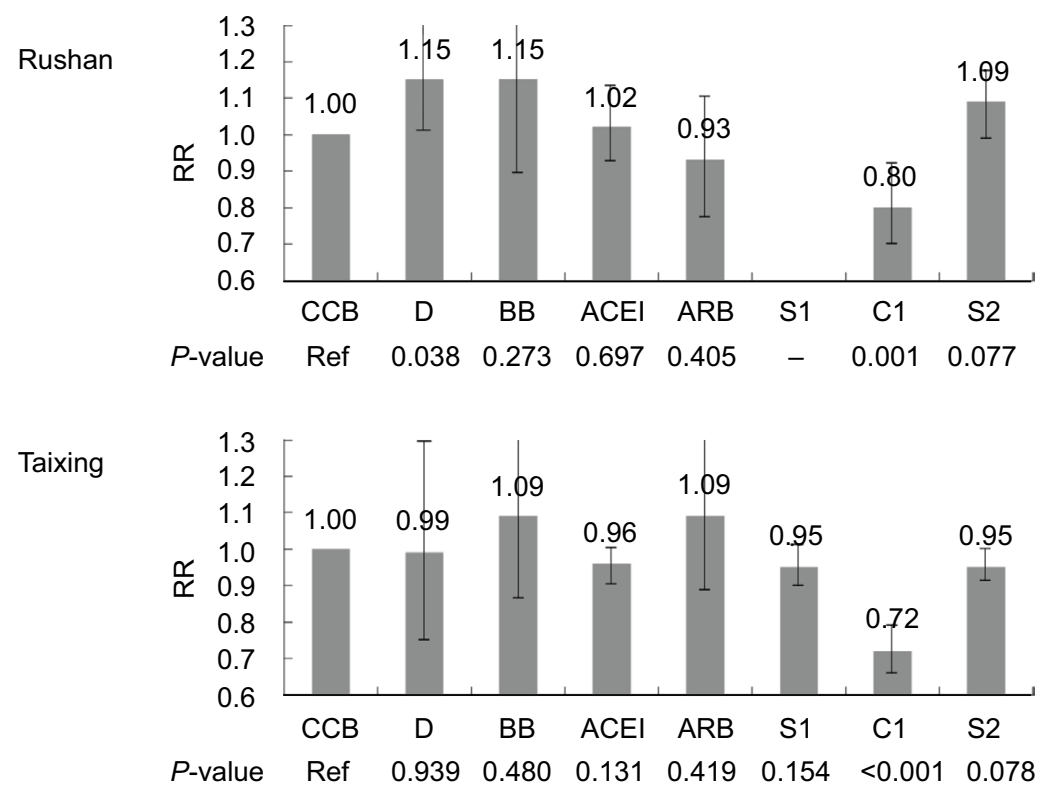

Yuhu
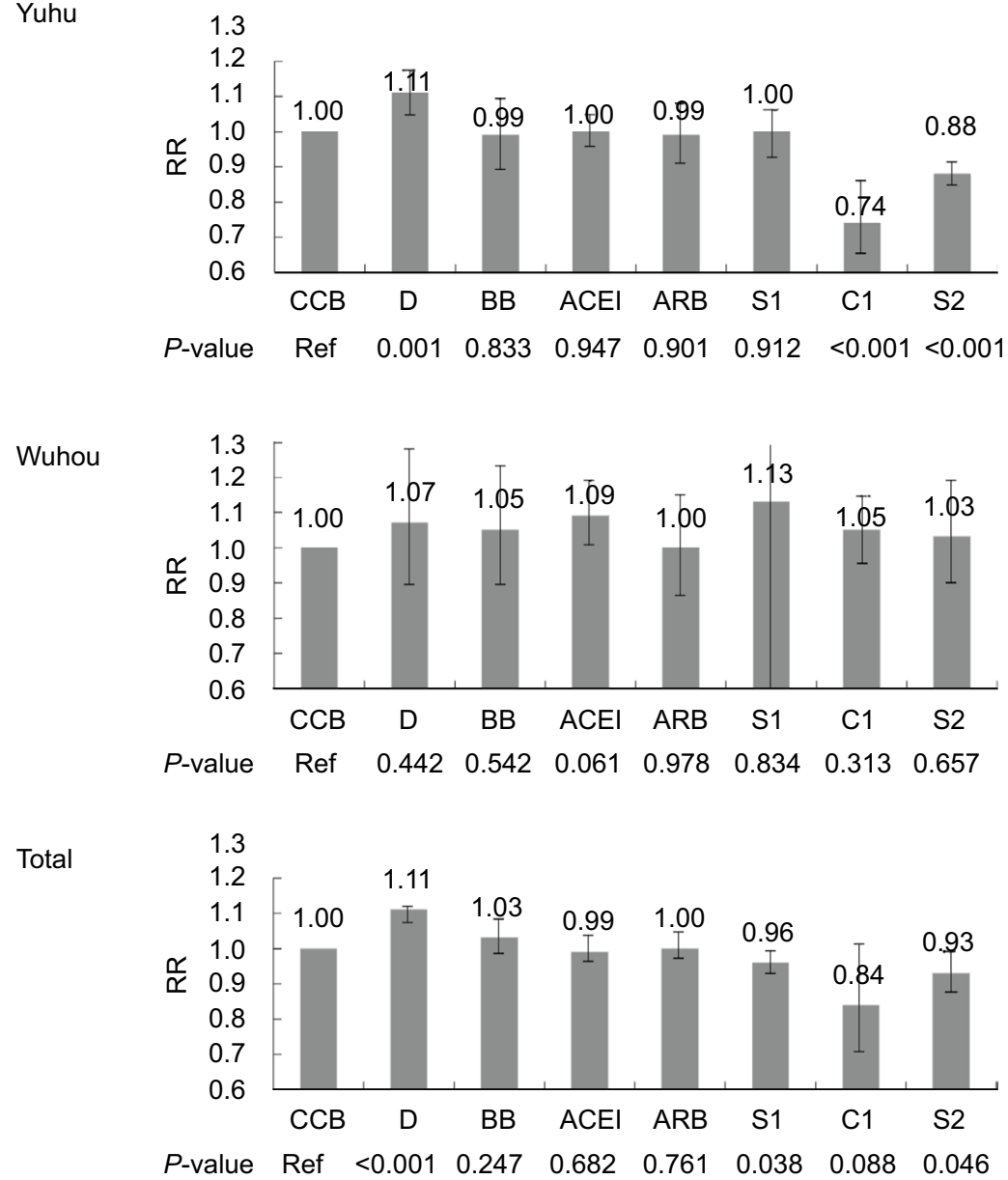

Figure I Comparison of I-year BP control between main drug uses in hypertensive patients with compliance.

Notes: Compliance with treatment means prescription of specific drug classes at each of four follow-ups. Ref, patients with CCB monotherapy were taken as the reference group; RR, risk ratio adjusted for gender, age, area, baseline SBP, baseline BMI, and diabetic history; SI, fixed-dose single-pill combinations only including first-line drugs; S2, single-pill combinations including both first-line and non-first-line drugs; $\mathrm{Cl}$, multiple-pill combination of frst-line drugs.

Abbreviations: ACEl, angiotensin-converting enzyme inhibitors; ARB, angiotensin receptor blockers; $B B$, beta-blocker; $B P$, blood pressure; $C C B$, calcium channel antagonist; D, diuretic. 
Table 4 One-year BP control for main drug uses in hypertensive populations with compliance

\begin{tabular}{|c|c|c|c|c|c|c|c|c|c|c|}
\hline & \multicolumn{5}{|c|}{ Number of patients with compliance } & \multicolumn{5}{|c|}{ Number (\%) of patients with BP control } \\
\hline & Rushan & Taixing & Yuhu & Wuhou & Total & Rushan & Taixing & Yuhu & Wuhou & Total \\
\hline$\overline{C C B}$ & 2,588 & 5,257 & 16,243 & 2,928 & 27,016 & $947(36.6)$ & $2,043(38.9)$ & $10,966(67.5)$ & $2,489(85.0)$ & $16,445(60.9)$ \\
\hline Diuretics & 725 & 132 & 1,504 & 132 & 2,493 & $302(4 \mid .7)$ & $49(37.1)$ & $\mathrm{I}, 14 \mathrm{I}(75.9)$ & $119(90.2)$ & $1,611(64.6)$ \\
\hline $\mathrm{BB}$ & 145 & 175 & 567 & 173 & 1,060 & $64(44.1)$ & $69(39.4)$ & $374(66.0)$ & $156(90.2)$ & $663(62.6)$ \\
\hline ACEI & 1,613 & 9,735 & 3,221 & 615 & 15,184 & $590(36.6)$ & $3,527(36.2)$ & $2,147(66.7)$ & 562 (9I.4) & $6,826(45.0)$ \\
\hline ARB & 388 & 231 & 656 & 217 & 1,492 & $140(36.1)$ & 91 (39.4) & $440(67.1)$ & I $83(84.3)$ & $854(57.2)$ \\
\hline SI & 0 & 4,596 & $\mathrm{I}, 074$ & 3 & 5,673 & 0 & $1,666(36.3)$ & $711(66.2)$ & $3(100.0)$ & $2,380(42.0)$ \\
\hline $\mathrm{Cl}$ & 1,027 & 2,000 & 350 & 674 & 4,051 & $296(28.8)$ & $518(25.9)$ & $|7|(48.9)$ & $607(90.1)$ & I,592 (39.3) \\
\hline S2 & 2,362 & 17,849 & 4,372 & 225 & 24,808 & 931 (39.4) & $6,514(36.5)$ & $2,562(58.6)$ & $198(88.0)$ & 10,205 (4I.I) \\
\hline
\end{tabular}

Notes: No patients persisted with multiple-pill combination of non-first-line drugs. SI, fixed-dose single-pill combinations only including first-line drugs; $\mathrm{S2}$, single-pill combinations including both first-line and non-first-line drugs; $\mathrm{Cl}$, multiple-pill combination of frst-line drugs.

Abbreviations: ACEl, angiotensin-converting enzyme inhibitors; ARB, angiotensin receptor blockers; BB, beta-blocker; BP, blood pressure; CCB, calcium channel antagonist.

urbanized areas, but a similar BP control was achieved in the highly urbanized Wuhou (RR, 1.05; 95\% CI, 0.96-1.15), compared with CCB monotherapy.

\section{Discussion}

To the best of our knowledge, this is the first populationbased evidence indicating compliance with medications and comparative effectiveness on BP control between main antihypertensive drugs used by patients with hypertension in primary health care sites of China.

We found that monotherapy with first-line recommended drugs such as CCBs, BBs, and diuretics had a fair BP control (Table 4; Figure 1), but few patients took BBs and diuretics in monotherapy. Although 2014 American guidelines based on RCTs did not take BBs as the first-line drug, ${ }^{1} \mathrm{BBs}$ in our study bore $\mathrm{BP}$ controls similar to $\mathrm{CCBs}$, as supported by the place of the first-line drug in current Chinese and European guidelines. ${ }^{2}$ In the developed countries, BBs remained the most frequently delivered drug with a stable prescription rate such as $21.9 \%-24.2 \%$ indicated by the American Veterans Affairs pharmacy data and $\sim 30 \%$ in Belgium of the Europe, ${ }^{12,13}$ much higher than the results from ours and China PEACE Million Persons Project. ${ }^{14} \mathrm{~A}$ survey suggested concerns on $\mathrm{BBs}$ from general practitioners such as bradycardia, metabolic disorders of blood glucose and lipids, and less effects of prevention for central aortic pressure and stroke in the elderly. ${ }^{15,16}$ Nevertheless, BBs own a definite effect on lowering BPs and protecting from cardiovascular events and current Chinese guidelines and expert consensus suggest an insufficient use of this drug in China. ${ }^{17}$ The hypertension guidelines underscore diuretics for all patients - particularly for Chinese patients characterized by salt-sensitivity. ${ }^{7}$ Newer antihypertensive agents such as CCBs and ACEIs are not superior to thiazide-based treatment in an RCT: ${ }^{18}$ moreover, in our study, diuretics seemed to have a likely better effect for BP control of those compliant to medication for a year in the real world. Notably, Chinese patients rarely took diuretics in monotherapy but frequently took this drug in fixed combinations with other drugs. This situation also happened in European countries such as Germany where general practitioners gave some reasons, such as insufficient BP-lowering capacity, concerns about side effects from monotherapy, and convenient availability of diuretics in fixed combinations. ${ }^{19,20}$ We also noted that combined treatment - single-pill or multiple-pill - generally failed to achieve BP control of the reference group (CCB monotherapy). The NPPHS-based single pills were almost diuretics-based fixed combinations with either first-line or non-first-line drugs in our study. Compared with single-pill combination, multiple-pill combination much more challenges the ability of general physicians. In our study, a better effect of first-line multiple-pill combination on controlling BP in the highly urbanized Wuhou, compared with other three less urbanized areas, suggested that BP control of hypertensive patients in primary health care sites could be improved.

Two recent studies from China PEACE Million Persons Project showed that the most commonly used medication class was CCBs that were prescribed in $55.2 \%$ of the treated hypertensive patients after screening for cardiovascular risk factors and available in $75.5 \%$ of primary health care sites. ${ }^{14,21}$ However, we found that a dramatic diversity between urban and rural primary health care sites lied in hypertensive patients with CCBs. Over a half of the patients in urban areas took CCBs, but single-pill drugs combined with nonfirst-line components were used more commonly in rural areas as compared with CCBs. The higher levels of use of monotherapy in urban areas may reflect the fact that they are generally better controlled at the time of referral. Medical insurance and cost limit of antihypertensive drugs prescribed 
Table 5 Baseline BPs and mean BP decreases from baseline of hypertensive populations with drug compliance

\begin{tabular}{|c|c|c|c|c|c|c|}
\hline \multirow[t]{2}{*}{ Group } & \multicolumn{3}{|c|}{ SBP $(\mathrm{mmHg})$} & \multicolumn{3}{|c|}{ DBP (mmHg) } \\
\hline & $\begin{array}{l}\text { At } \\
\text { baseline }\end{array}$ & $\begin{array}{l}\text { Mean decrease } \\
\text { from baseline }^{\mathrm{a}}\end{array}$ & $\begin{array}{l}P \text {-value for } \\
\text { change }\end{array}$ & $\begin{array}{l}\text { At } \\
\text { baseline }\end{array}$ & $\begin{array}{l}\text { Mean decrease } \\
\text { from baseline }^{\mathrm{a}}\end{array}$ & $\begin{array}{l}P \text {-value for } \\
\text { change }\end{array}$ \\
\hline \multicolumn{7}{|l|}{ Rushan } \\
\hline CCB $(n=2,588)$ & $154.3 \pm 20.5$ & I8.7 (I7.8 to 19.6) & $<0.001$ & $91.9 \pm 11.3$ & 9.8 (9.3 to 10.3$)$ & $<0.001$ \\
\hline$D(n=725)$ & $|57.9 \pm 2| . \mid$ & 23.1 (2I.5 to 24.7$)$ & $<0.00$ I & $92.5 \pm 11.6$ & $10.6(9.7$ to II.5) & $<0.001$ \\
\hline$B B(n=\mid 45)$ & $147.4 \pm 18.3$ & $16.0(12.7$ to 19.3$)$ & $<0.001$ & $89.7 \pm 10.3$ & $8.5(6.7$ to 10.3$)$ & $<0.001$ \\
\hline ACEI $(n=I, 6 \mid 3)$ & $157.8 \pm 20.0$ & 21.6 (20.5 to 22.7$)$ & $<0.001$ & $93.7 \pm 10.9$ & 10.6 (I0.0 to II. 2$)$ & $<0.001$ \\
\hline ARB $(n=388)$ & $146.2 \pm 18.6$ & $10.3(8.3$ to 12.3$)$ & $<0.001$ & $90.8 \pm 11.9$ & $8.0(6.7$ to 9.3$)$ & $<0.001$ \\
\hline$S I(n=0)$ & - & - & - & - & - & - \\
\hline$C I(n=I, 027)$ & $157.0 \pm 21.8$ & I8.I (16.6 to 19.6) & $<0.001$ & $93.5 \pm 12.1$ & $10.0(9.2$ to 10.8$)$ & $<0.001$ \\
\hline$S 2(n=2,362)$ & $157.2 \pm 20.9$ & 20.5 (19.6 to 21.4$)$ & $<0.001$ & $93.0 \pm 11.2$ & I0.1 (9.6 to 10.6) & $<0.001$ \\
\hline Subtotal $(n=8,848)$ & $155.9 \pm 20.8$ & $19.6(19.1$ to 20.1$)$ & $<0.001$ & $92.7 \pm 11.4$ & $10.0(9.7$ to 10.3$)$ & $<0.001$ \\
\hline \multicolumn{7}{|l|}{ Taixing } \\
\hline CCB $(n=5,257)$ & $138.6 \pm 16.4$ & $4.6(4.1$ to 5.1$)$ & $<0.001$ & $85.6 \pm 9.8$ & 2.7 (2.4 to 3.0$)$ & $<0.001$ \\
\hline$D(n=132)$ & $139.4 \pm 18.1$ & 5.5 (2.5 to 8.5$)$ & 0.001 & $85.7 \pm 10.3$ & $3.0(1.1$ to 4.9$)$ & 0.003 \\
\hline$B B(n=175)$ & $140.2 \pm 15.9$ & $7.6(5.1$ to 10.1$)$ & $<0.001$ & $85.6 \pm 9.8$ & 3.6 (2.0 to 5.2$)$ & $<0.001$ \\
\hline ACEI $(n=9,735)$ & $140.6 \pm \mid 7.7$ & 5.8 (5.4 to 6.2$)$ & $<0.001$ & $86.0 \pm 10.5$ & 3.0 (2.8 to 3.2$)$ & $<0.001$ \\
\hline ARB $(n=231)$ & $138.9 \pm 17.3$ & 3.7 (1.2 to 6.2$)$ & 0.004 & $85.6 \pm 10.8$ & 2.1 (0.6 to 3.6$)$ & 0.006 \\
\hline SI $(n=4,596)$ & $14 \mid .5 \pm 17.9$ & 6.8 (6.3 to 7.3$)$ & $<0.001$ & $86.1 \pm 10.4$ & $3.0(2.7$ to 3.3$)$ & $<0.001$ \\
\hline $\mathrm{Cl}(\mathrm{n}=2,000)$ & $143.7 \pm \mid 8.8$ & 5.7 (4.8 to 6.6$)$ & $<0.001$ & $87.7 \pm 11.2$ & $2.8(2.3$ to 3.3$)$ & $<0.001$ \\
\hline$S 2(n=\mid 7,849)$ & $140.3 \pm 17.1$ & 5.7 (5.4 to 6.0$)$ & $<0.001$ & $85.3 \pm 10.1$ & 2.6 (2.4 to 2.8$)$ & $<0.001$ \\
\hline Subtotal $(n=39,975)$ & $140.5 \pm \mid 7.4$ & $5.7(5.5$ to 5.9$)$ & $<0.001$ & $85.7 \pm 10.3$ & 2.7 (2.6 to 2.8$)$ & $<0.001$ \\
\hline \multicolumn{7}{|l|}{ Yuhu } \\
\hline$C C B(n=16,243)$ & $133.3 \pm 17.2$ & $4.4(4.1$ to 4.7$)$ & $<0.001$ & $81.1 \pm 10.0$ & $2.9(2.7$ to 3.1$)$ & $<0.001$ \\
\hline$D(n=I, 504)$ & $130.3 \pm 16.5$ & 3.5 (2.6 to 4.4$)$ & $<0.001$ & $80.9 \pm 9.6$ & 3.1 (2.5 to 3.7$)$ & $<0.001$ \\
\hline $\mathrm{BB}(\mathrm{n}=567)$ & $133.8 \pm 16.7$ & 5.0 (3.5 to 6.5$)$ & $<0.001$ & $80.8 \pm 8.8$ & 3.1 (2.3 to 3.9$)$ & $<0.001$ \\
\hline ACEI $(n=3,221)$ & $134.6 \pm 18.2$ & $5.4(4.7$ to 6.1$)$ & $<0.001$ & $82.3 \pm 10.4$ & 4.1 (3.7 to 4.5$)$ & $<0.001$ \\
\hline ARB $(n=656)$ & $132.6 \pm 15.4$ & 4.1 (2.8 to 5.4$)$ & $<0.001$ & $80.3 \pm 9.6$ & 2.7 (I.3 to 4.1$)$ & $<0.001$ \\
\hline SI $(n=I, 074)$ & $132.9 \pm 15.2$ & 3.4 (2.3 to 4.5$)$ & $<0.001$ & $81.6 \pm 9.4$ & 2.8 (2.2 to 3.4$)$ & $<0.001$ \\
\hline $\mathrm{Cl}(\mathrm{n}=350)$ & $136.7 \pm 19.6$ & $4.7(2.4$ to 7.0$)$ & $<0.001$ & $82.7 \pm 10.8$ & 2.9 (1.6 to 4.2$)$ & $<0.001$ \\
\hline$S 2(n=4,372)$ & $134.1 \pm 17.5$ & 3.6 (3.0 to 4.2$)$ & $<0.001$ & $82.3 \pm 10.2$ & 2.8 (2.4 to 3.2$)$ & $<0.001$ \\
\hline Subtotal $(n=27,987)$ & $133.3 \pm 17.3$ & $4.3(4.1$ to 4.5$)$ & $<0.00$ I & $81.4 \pm 10.0$ & 3.1 (3.0 to 3.2 ) & $<0.001$ \\
\hline \multicolumn{7}{|l|}{ Wuhou } \\
\hline CCB $(n=2,928)$ & $127.4 \pm 7.8$ & $-0.8(-1.1$ to -0.5$)$ & $<0.00$ I & $76.5 \pm 6.4$ & $-0.1(-0.4$ to 0.2$)$ & 0.344 \\
\hline$D(n=132)$ & $128.2 \pm 6.8$ & 1.4 (0 to 2.8$)$ & $<0.001$ & $75.8 \pm 6.9$ & $1.5(-0.2$ to 3.2$)$ & 0.072 \\
\hline$B B(n=173)$ & $126.4 \pm 8.0$ & $-1.7(-3.1$ to -0.3$)$ & 0.016 & $75.4 \pm 6.4$ & $-1.9(-3.1$ to -0.7$)$ & 0.002 \\
\hline ACEI $(n=6 \mid 5)$ & $128.0 \pm 5.6$ & $3.0(2.2$ to 3.8$)$ & $<0.001$ & $76.0 \pm 5.8$ & 1.2 (0.6 to I.8) & $<0.001$ \\
\hline ARB $(n=2 \mid 7)$ & $127.5 \pm 7.1$ & $-0.6(-1.8$ to 0.6$)$ & 0.320 & $76.5 \pm 6.4$ & $-0.7(-1.8$ to 0.4$)$ & 0.184 \\
\hline$S I(n=3)$ & $123.0 \pm 17.6$ & $-4.3(-19.1$ to 10.5$)$ & 0.623 & $73.3 \pm 4.2$ & $-5.3(-19.1$ to 8.5$)$ & 0.529 \\
\hline $\mathrm{Cl}(\mathrm{n}=674)$ & $126.2 \pm 8.0$ & $-1.8(-2.6$ to -1.0$)$ & $<0.001$ & $75.1 \pm 6.3$ & $-1.7(-2.3$ to -1.1$)$ & $<0.001$ \\
\hline$S 2(n=225)$ & $127.6 \pm 7.4$ & $-0.1(-1.3$ to 1.1$)$ & 0.860 & $76.4 \pm 6.3$ & $-0.7(-1.7$ to 0.3$)$ & 0.158 \\
\hline Subtotal $(n=4,967)$ & $127.3 \pm 7.5$ & $-0.4(-0.7$ to -0.1$)$ & 0.005 & $76.3 \pm 6.3$ & $-0.3(-0.5$ to -0.1$)$ & 0.022 \\
\hline \multicolumn{7}{|l|}{ Total } \\
\hline $\mathrm{CCB}(\mathrm{n}=27,016)$ & $135.7 \pm 18.0$ & $5.3(5.1$ to 5.5$)$ & $<0.001$ & $82.5 \pm 10.5$ & $3.2(3.1$ to 3.3$)$ & $<0.001$ \\
\hline$D(n=2,493)$ & $138.7 \pm 2 \mid .6$ & 9.2 (8.4 to 10.0$)$ & $<0.001$ & $84.3 \pm 11.5$ & 5.2 (4.7 to 5.7$)$ & $<0.001$ \\
\hline BB $(n=I, 060)$ & $135.5 \pm 16.9$ & $5.9(4.8$ to 7.0$)$ & $<0.001$ & $82.0 \pm 9.8$ & $3.1(2.5-3.7)$ & $<0.001$ \\
\hline ACEI $(n=15,184)$ & $140.7 \pm 19.0$ & $7.2(6.9$ to 7.5$)$ & $<0.001$ & $85.6 \pm 11.0$ & 3.9 (3.7 to 4.1$)$ & $<0.001$ \\
\hline ARB $(n=1,492)$ & $136.4 \pm|7|$. & $5.0(4.1$ to 5.9$)$ & $<0.001$ & $83.3 \pm 17.3$ & $3.5(2.9$ to 4.1$)$ & $<0.001$ \\
\hline SI $(n=5,673)$ & $139.8 \pm 17.8$ & 6.I (5.6 to 6.6) & $<0.001$ & $85.2 \pm 10.4$ & 2.9 (2.6 to 3.2$)$ & $<0.001$ \\
\hline $\mathrm{Cl}(\mathrm{n}=4,05 \mathrm{I})$ & $143.5 \pm 20.9$ & 7.3 (6.6 to 8.0$)$ & $<0.001$ & $86.6 \pm 12.3$ & 3.9 (3.5 to 4.3$)$ & $<0.001$ \\
\hline$S 2(n=24,808)$ & $140.7 \pm \mid 8.5$ & 6.7 (6.5 to 6.9$)$ & $<0.001$ & $85.5 \pm 10.6$ & 3.3 (3.2 to 3.4$)$ & $<0.001$ \\
\hline Total $(n=81,777)$ & $138.9 \pm 18.7$ & 6.4 (6.3 to 6.5$)$ & $<0.001$ & $84.4 \pm 10.8$ & 3.5 (3.4 to 3.6$)$ & $<0.001$ \\
\hline
\end{tabular}

Notes: aMeans with $95 \%$ confidence intervals. SI, fixed-dose single-pill combinations only including first-line drugs; S2, single-pill combinations including both first-line and non-first-line drugs; $\mathrm{CI}$, multiple-pill combination of frst-line drugs.

Abbreviations: ACEI, angiotensin-converting enzyme inhibitors; ARB, angiotensin receptorblockers; $\mathrm{BB}$, beta-blocker; $\mathrm{BP}$, blood pressure; CCB, calcium channel antagonist; DBP, diastolic blood pressure; SBP, systolic blood pressure. 
by general practitioners also partly led to a different drug use between areas. ${ }^{21}$ Compliance with drugs is associated with BP control. Our study generally showed that both CCBs and single-pill combination bore fare compliance. This could lead to much frequency in use of these two drug classes. Our findings on diversity of drug choice and compliance between areas and between specific drugs reflected a complicated context; health policies and related behaviors of patients and general practitioners as well as efficacy, side effect, and cost of a drug itself would have impact on the effectiveness of antihypertensive drugs in the real world.

BP control also depends on many factors in the real world besides a drug choice and compliance. As shown in Table 4, difference between urban and rural regions in hypertension control far exceeds the difference between medication classes, suggesting a profoundly structural - rather than pharmacological - cause of inadequate hypertension control in China. However, in the population with compliance to antihypertensive drugs, rural individuals with higher baseline BPs had more benefits on BP decreases, compared with urban individuals (Table 5); this suggested that drugs could play a leading role in BP control for this population. Patients involved in this service system have much chance to make their BPs controlled, particularly during a free follow-up, including BP measurements, health education, and transfer of treatment by primary health care sites; these accesses to health care services increase adherence to pharmacological therapy. Obviously, following a regular follow-up, patients in more urbanized areas achieved better BP controls; this likely resulted from lower initial BP levels, more shares of patients from a referral of better hospitals, and better drug uses. Nevertheless, $50.2 \%$ of BP control for the population with a normative follow-up management in our limited areas was much higher than $9.7 \%$ of BP control in current China and similar to $52.5 \%$ in the United States that required similar services such as appropriate lifestyle modifications, evidencebased treatment, and adequate follow-ups. .,22,23 $^{2}$

Lastly, involving patients into the NPPHS as much as possible is essential to effect primary health care services. Given a constitution of hypertension on gender and age, this service system of four areas involved less male and young patients likely due to their worse compliance to health care services (Table 2). The NPPHS includes a free establishment of individual health care files for all residents, a free BP measurement per year or at the first clinic visit for people aged $\geq 35$ years, and free check-ups for individuals aged $\geq 65$ years ${ }^{7}$ these services could improve detection of hypertension. We, however, also emphasize an active screening for hypertension in the setting of less ideal awareness for hypertensive condition $(20.1 \%$ in rural areas and $32.5 \%$ in urban areas of China), ${ }^{21}$ as supported by a recent study conducted in Beijing; in this study, hypertensive patients newly identified by active screening accounted for $30 \%$ of all patients in an urban community. ${ }^{24}$ Next, more secondary or tertiary hospitals in urban areas than those in rural ones likely led to a lower management proportion of patients in residents and less hypertensive patients - particularly patients with stage 2-3 hypertension - transferred to primary health care sites. This situation is related to many reasons such as profit-making of secondary or tertiary hospitals, weak attraction of primary health care sites for patients due to a level of diagnosis and treatment, and blocked interchange of information between medical institutes. Thus, we observed a relatively small population size of patients and a low rate of medications in the highly urbanized Wuhou, that is, 47,198 patients of 1.08 million people and $14.3 \%$ (Tables 1 and 2), respectively.

\section{Strength and limitations}

Our study has several strengths. First, this study supplemented evidence beyond RCTs and translated efficacy-based evidence into a likely widespread adoption of a generalized population. ${ }^{25}$ Second, this study involved all qualified patients of the four areas; this big-data-based method avoided selective bias and guaranteed authenticity in representative areas and may predict the future of epidemiology. ${ }^{26-28}$ Third, this study is of follow-up and can truly reflect compliance with treatment and BP control within 1 year. Lastly, the information of drugs in this study - usually difficult to obtain accurately in classical epidemiological fields - was more reliable due to extracting from a real-time record by general practitioners and monitoring by the Center for Disease Control and Prevention.

There are some limitations in this study. Prospective studies with cardiovascular events, such as stroke and acute myocardial infarction, as outcomes would have to warrant our findings in the future. Next, the non-random assignment to drugs, analysis restricted to only those individuals who persisted in therapy, and the referral filter that made a fraction of the hypertensive individuals fail to enter into this cohort could limit interpretation of the data, but our universal set of the NPPHS-based hypertensive patients in the four typical areas reflected a real situation of drug use, and based on this big data set, we compared drugs after adjustment for confounders. Also, we have to acknowledge some limitations of estimating compliance using electronic health care data. For instance, we have to define compliance-based four follow-ups within 1 year per the national norm; this time interval defined 
between follow-ups is overall likely longer than that in MPR - the standard accepted for evaluating compliance using retrospective data. ${ }^{10}$ Nevertheless, the public health practice needs an accepted quantitative definition on compliance with treatment that is lacking in the current norm of NPPHS of China; the MPR may be one of our choices. In addition, a hint of BP measurements from electronic sphygmomanometers could add heterogenicity of measurements; however, this low proportion of using electronic sphygmomanometers in the NPPHS and a consistence between electronic and mercury sphygmomanometer could not change our results. ${ }^{29}$

\section{Conclusion}

The NPPHS could improve choice, compliance, and combination of drugs in rural areas and enhance a referral of hypertensive patients from secondary or tertiary hospitals into the primary health care sites as much as possible in urban areas and drug use such as diuretics may be strengthened in primary health care sites.

\section{Acknowledgments}

We acknowledge Shandong Center for Disease Control and Prevention, Jiangsu Center for Disease Control and Prevention, Hunan Center for Disease Control and Prevention, and Sichuan Center for Disease Control and Prevention who supported work within their own administration areas. We also acknowledge Professor Kunlin Jin and Professor Xiang Gao who contributed valuable advice during the writing of this manuscript. We also acknowledge the funding from Operation of China's CDC Public Health Emergency Response Mechanism, 1310 31001000150001. Jixiang Ma currently serves for the Division of Non-communicable Disease Control and Community Health, Chinese Center for Disease Control and Prevention; Zhaoxue Yin, also from this institute, contributed to the publication.

\section{Disclosure}

The authors report no conflicts of interest in this work.

\section{References}

1. James PA, Oparil S, Carter BL, et al. 2014 evidence-based guideline for the management of high blood pressure in adults: report from the panel members appointed to the Eighth Joint National Committee (JNC 8). JAMA. 2014;311(5):507-520.

2. Mancia G, Fagard R, Narkiewicz K, et al. 2013 ESH/ESC guidelines for the management of arterial hypertension: the Task Force for the Management of Arterial Hypertension of the European Society of Hypertension (ESH) and of the European Society of Cardiology (ESC). Eur Heart J. 2013;34(28):2159-2219.

3. Laken MA, Dawson R, Engelman O, et al. Comparative effectiveness research in the "real" world: lessons learned in a study of treatmentresistant hypertension. J Am Soc Hypertens. 2013;7(1):95-101.
4. National Health and Family Planning Commission of China. [2015 Statistical bulletin on medical and health institutions of China; 2015]. Available from: http://www.nhfpc.gov.cn/mohwsbwstjxxzx/. Accessed September 10, 2018. Chinese.

5. Chen Z. Launch of the health-care reform plan in China. Lancet. 2009;373(9672):1322-1324.

6. Li Y, Yang L, Wang L, et al. Burden of hypertension in China: A nationally representative survey of 174,621 adults. Int J Cardiol. 2017;227:516-523.

7. Liu S, Writing Group of 2010 Chinese Guidelines for the Management of Hypertension. 2010 Chinese guidelines for the management of hypertension. Zhonghua Xin Xue Guan Bing Za Zhi. 2011;39(7):579-615. Chinese.

8. National Health Ministry of China. 2011 [Norm of National Primary Public Health Services; 2011]. Available from: http://www.moh.gov. cn/jws/s3577/201105/51780.shtml. Accessed September 18, 2018. Chinese.

9. Writing Group of Chinese Guidelines for blood pressure measurements. Chinese Guidelines for blood pressure measurements. Clin J Hypertens. 2011;19(12):1101-1115. Chinese.

10. Halpern MT, Khan ZM, Schmier JK, et al. Recommendations for evaluating compliance and persistence with hypertension therapy using retrospective data. Hypertension. 2006;47(6):1039-1048.

11. Deddens JA, Petersen MR. Approaches for estimating prevalence ratios. Occup Environ Med. 2008;65(7):481, 501-506.

12. Lopez J, Meier J, Cunningham F, Siegel D. Antihypertensive medication use in the Department of Veterans Affairs: a national analysis of prescribing patterns from 2000 to 2002. Am J Hypertens. 2004;17(12 Pt 1):1095-1099.

13. Wolf M, Heuten HG, de Swaef A, de Falleur M, Verpooten GA. The evolution of hypertension treatment in Belgium, a pharmacoepidemiological study. Acta Cardiol. 2012;67(2):147-152.

14. Lu J, Lu Y, Wang X, et al. Prevalence, awareness, treatment, and control of hypertension in China: data from 1.7 million adults in a populationbased screening study (China PEACE Million Persons Project). Lancet. 2017;390(10112):2549-2558.

15. Wu Y, Wang Z, Gao R. A survey on perception and knowledge of Chinese health care professionals in prevention and control of hypertension. Chin J Cardiol. 2004;32(3):264-269. Chinese.

16. Zhang $\mathrm{H}$, Zhang D, Li J. The application of $\beta$-receptor blockers in patients with coronary heart disease in China. J Chin Cardiol (China). 2011;27(6):422-425. Chinese.

17. Committee on Hypertension, Chinese Medical Doctor Association. Guidance and advices on $\beta$-receptor blockers in hypertension. Chin J Frontiers Med Sci. 2013;5(4):58-66. Chinese.

18. ALLHAT Officers and Coordinators for the ALLHAT Collaborative Research Group. The Antihypertensive and Lipid-Lowering Treatment to Prevent Heart Attack Trial. Major outcomes in high-risk hypertensive patients randomized to angiotensin-converting enzyme inhibitor or calcium channel blocker vs diuretic: The Antihypertensive and LipidLowering Treatment to Prevent Heart Attack Trial (ALLHAT). JAMA. 2002;288(23):2981-2997.

19. Kuehlein T, Laux G, Gutscher A, et al. Diuretics for hypertension - an inconsistency in primary care prescribing behaviour. Curr Med Res Opin. 2011;27(3):497-502.

20. Lamers H, Joos S, Goetz K, et al. Diuretics for hypertension-reasons for a contradiction in primary care prescribing behavior: a qualitative study. J Clin Hypertens. 2012;14(10):680-685.

21. Su M, Zhang Q, Bai X, et al. Availability, cost, and prescription patterns of antihypertensive medications in primary health care in China: a nationwide cross-sectional survey. Lancet. 2017;390(10112):2559-2568.

22. Go AS, Bauman MA, Coleman King SM, et al. An effective approach to high blood pressure control: a science advisory from the American Heart Association, the American College of Cardiology, and the Centers for Disease Control and Prevention. Hypertension. 2014;63(4): 878-885. 
23. Chobanian AV, Bakris GL, Black HR, et al. The Seventh Report of the Joint National Committee on Prevention, Detection, Evaluation, and Treatment of High Blood Pressure: the JNC 7 report. JAMA. 2003;289(19):2560-2572.

24. Jiang B, Liu H, Ru X, Zhang H, Wu S, Wang W. Hypertension detection, management, control and associated factors among residents accessing community health services in Beijing. Sci Rep. 2014;4:4845.

25. Dreyer NA, Tunis SR, Berger M, Ollendorf D, Mattox P, Gliklich R. Why observational studies should be among the tools used in comparative effectiveness research. Health Aff. 2010;29(10):1818-1825.

26. Sim I. Two Ways of Knowing: Big Data and Evidence-Based Medicine. Ann Intern Med. 2016;164(8):562-563.
27. Khoury MJ. Planning for the Future of Epidemiology in the Era of Big Data and Precision Medicine. Am J Epidemiol. 2015;182(12): 977-979.

28. Mooney SJ, Westreich DJ, El-Sayed AM. Commentary: Epidemiology in the era of big data. Epidemiology. 2015;26(3):390-394.

29. $\mathrm{Xu} \mathrm{H}, \mathrm{Hou} \mathrm{L}, \mathrm{Zuo} \mathrm{H}$, et al. Accuracy of pulse wave and oscillometric electronic sphygmomanometers for blood pressure measurements in obese people. Chin J Hypertens. 2017;25(4):338-344. Chinese.

30. Wang Z, Chen Z, Zhang L, et al. Status of Hypertension in China: Results From the China Hypertension Survey, 2012-2015. Circulation. 2018;137(22):2344-2356. 


\section{Supplementary material}

Table SI Baseline characteristics of hypertensive populations with compliance to different drugs

\begin{tabular}{|c|c|c|c|c|c|c|}
\hline & Age (years) & Male (\%) & SBP $(\mathbf{m m H g})$ & DBP (mmHg) & Diabetic history (\%) & BMI $\left(\mathrm{kg} / \mathrm{m}^{2}\right)$ \\
\hline \multicolumn{7}{|l|}{ Rushan } \\
\hline CCB $(n=2,588)$ & $66.4 \pm 9.9$ & 39.0 & $154.3 \pm 20.5$ & $91.9 \pm 11.3$ & 10.2 & $25.8 \pm 3.1$ \\
\hline$D(n=725)$ & $64.5 \pm 10.0$ & 29.7 & $157.9 \pm 21.1$ & $92.5 \pm 11.6$ & 10.3 & $26.2 \pm 3.3$ \\
\hline$B B(n=\mid 45)$ & $65.7 \pm 10.1$ & 40.7 & $|47.4 \pm| 8.3$ & $89.7 \pm 10.3$ & 6.9 & $25.9 \pm 3.0$ \\
\hline $\operatorname{ACEI}(n=|, 6| 3)$ & $64.0 \pm 10.4$ & 36.8 & $157.8 \pm 20.0$ & $93.7 \pm 10.9$ & 8.8 & $25.9 \pm 3.3$ \\
\hline ARB $(n=388)$ & $63.8 \pm 10.5$ & 39.4 & $146.2 \pm 18.6$ & $90.8 \pm 11.9$ & 10.1 & $26.1 \pm 3.1$ \\
\hline$S I(n=0)$ & - & - & - & - & - & - \\
\hline $\mathrm{Cl}(\mathrm{n}=\mathrm{I}, 027)$ & $65.6 \pm 10.1$ & 41.6 & $157.0 \pm 21.8$ & $93.5 \pm 12.1$ & 10.5 & $26.3 \pm 3.4$ \\
\hline$S 2(n=2,362)$ & $65.9 \pm 10.5$ & 32.3 & $157.2 \pm 20.9$ & $93.0 \pm 11.2$ & 7.9 & $24.1 \pm 3.3$ \\
\hline Subtotal $(n=8,848)$ & $65.4 \pm 10.3$ & 36.4 & $155.9 \pm 20.8$ & $92.7 \pm 11.4$ & 9.3 & $25.9 \pm 3.3$ \\
\hline \multicolumn{7}{|l|}{ Taixing } \\
\hline CCB $(n=5,257)$ & $66.8 \pm 11.9$ & 46.2 & $138.6 \pm 16.4$ & $85.6 \pm 9.8$ & 12.7 & $23.9 \pm 3.1$ \\
\hline$D(n=\mid 32)$ & $64.7 \pm 10.6$ & 37.9 & $139.4 \pm \mid 8.1$ & $85.7 \pm 10.3$ & 9.1 & $24.7 \pm 3.6$ \\
\hline$B B(n=175)$ & $66.6 \pm 11.5$ & 53.1 & $140.2 \pm 15.9$ & $85.6 \pm 9.8$ & 9.1 & $24.1 \pm 3.3$ \\
\hline ACEI $(n=9,735)$ & $67.6 \pm 11.6$ & 53.3 & $140.6 \pm 17.7$ & $86.0 \pm 10.5$ & 10.2 & $24.0 \pm 3.2$ \\
\hline ARB $(n=231)$ & $67.7 \pm 11.8$ & 44.2 & $138.9 \pm 17.3$ & $85.6 \pm 10.8$ & 12.1 & $24.8 \pm 3.2$ \\
\hline SI $(n=4,596)$ & $68.0 \pm 11.4$ & 48.8 & $141.5 \pm 17.9$ & $86.1 \pm 10.4$ & 12.1 & $24.2 \pm 3.4$ \\
\hline $\mathrm{Cl}(\mathrm{n}=2,000)$ & $66.6 \pm 11.3$ & 53.0 & $143.7 \pm 18.8$ & $87.7 \pm 11.2$ & 13.7 & $24.9 \pm 3.4$ \\
\hline$S 2(n=17,849)$ & $68.6 \pm \mathrm{II} .4$ & 42.6 & $140.3 \pm 17.1$ & $85.3 \pm 10.1$ & 10.9 & $23.9 \pm 3.2$ \\
\hline Subtotal $(n=39,957)$ & $67.9 \pm 11.5$ & 45.4 & $140.5 \pm 17.4$ & $85.7 \pm 10.3$ & 11.2 & $24.0 \pm 3.3$ \\
\hline \multicolumn{7}{|l|}{ Yuhu } \\
\hline $\mathrm{CCB}(\mathrm{n}=16,243)$ & $67.8 \pm 10.1$ & 43.3 & $133.3 \pm 17.2$ & $81.1 \pm 10.0$ & 9.9 & $23.7 \pm 3.0$ \\
\hline$D(n=1,504)$ & $67.3 \pm 10.8$ & 42.7 & $130.3 \pm 16.5$ & $80.9 \pm 9.6$ & 8.6 & $23.8 \pm 3.0$ \\
\hline$B B(n=567)$ & $68.6 \pm 9.2$ & 42.2 & $133.8 \pm 16.7$ & $80.8 \pm 8.8$ & 18.2 & $23.9 \pm 3.0$ \\
\hline ACEI $(n=3,221)$ & $65.8 \pm 10.5$ & 45.2 & $134.6 \pm 18.2$ & $82.3 \pm 10.4$ & 10.5 & $24.1 \pm 3.2$ \\
\hline ARB $(n=656)$ & $66.5 \pm 9.8$ & 42.1 & $132.6 \pm \mid 5.4$ & $80.3 \pm 9.6$ & 18.6 & $24.4 \pm 3.1$ \\
\hline SI $(n=1,074)$ & $66.0 \pm 9.7$ & 43.0 & $132.9 \pm 15.2$ & $81.6 \pm 9.4$ & 11.7 & $24.2 \pm 3.4$ \\
\hline $\mathrm{Cl}(\mathrm{n}=350)$ & $64.7 \pm 10.8$ & 46.0 & $136.7 \pm 19.6$ & $82.7 \pm 10.8$ & 6.3 & $24.2 \pm 3.3$ \\
\hline$S 2(n=4,372)$ & $66.1 \pm 9.9$ & 39.6 & $134.1 \pm 17.5$ & $82.3 \pm 10.2$ & 8.1 & $24.1 \pm 3.1$ \\
\hline Subtotal $(n=27,987)$ & $67.2 \pm 10.1$ & 42.9 & $133.4 \pm 17.3$ & $81.4 \pm 10.0$ & 10.0 & $23.8 \pm 3.0$ \\
\hline \multicolumn{7}{|l|}{ Wuhou } \\
\hline CCB $(n=2,928)$ & $63.4 \pm 10.9$ & 49.8 & $127.4 \pm 7.8$ & $76.5 \pm 6.4$ & 27.2 & $23.3 \pm 2.6$ \\
\hline$D(n=132)$ & $61.9 \pm 13.1$ & 46.2 & $128.2 \pm 6.8$ & $75.8 \pm 6.9$ & 26.5 & $23.3 \pm 2.6$ \\
\hline$B B(n=173)$ & $63.8 \pm 12.2$ & 57.2 & $126.4 \pm 8.0$ & $75.4 \pm 6.4$ & 29.5 & $23.7 \pm 2.8$ \\
\hline ACEI $(n=6 \mid 5)$ & $65.5 \pm 11.9$ & 51.5 & $128.0 \pm 5.6$ & $76.0 \pm 5.8$ & 42.3 & $22.5 \pm 2.4$ \\
\hline $\operatorname{ARB}(n=2 \mid 7)$ & $65.7 \pm 11.9$ & 39.6 & $127.5 \pm 7.1$ & $76.5 \pm 6.4$ & 31.8 & $23.7 \pm 2.8$ \\
\hline$S I(n=3)$ & $61.3 \pm 13.3$ & 33.3 & $123.0 \pm 17.6$ & $73.3 \pm 4.2$ & 33.3 & $28.8 \pm 5.7$ \\
\hline $\mathrm{Cl}(\mathrm{n}=674)$ & $67.1 \pm 11.5$ & 46.6 & $126.2 \pm 8.0$ & $75.1 \pm 6.3$ & 32.5 & $23.8 \pm 2.9$ \\
\hline$S 2(n=225)$ & $65.9 \pm 11.3$ & 40.4 & $127.6 \pm 7.4$ & $76.4 \pm 6.3$ & 19.6 & $23.6 \pm 2.6$ \\
\hline Subtotal $(n=4,967)$ & $63.5 \pm 11.3$ & 48.6 & $127.3 \pm 7.5$ & $76.3 \pm 6.3$ & 29.7 & $23.3 \pm 2.7$ \\
\hline \multicolumn{7}{|l|}{ Total } \\
\hline $\mathrm{CCB}(\mathrm{n}=27,016)$ & $67.0 \pm 10.6$ & 44.2 & $|35.7 \pm| 8.0$ & $82.5 \pm 10.5$ & 12.4 & $23.9 \pm 3.1$ \\
\hline$D(n=2,493)$ & $66.1 \pm 10.8$ & 38.8 & $138.7 \pm 2 \mid .6$ & $84.3 \pm 11.5$ & 10.1 & $24.5 \pm 3.3$ \\
\hline $\mathrm{BB}(\mathrm{n}=1,060)$ & $67.1 \pm 10.4$ & 43.9 & $135.5 \pm 16.9$ & $82.0 \pm 9.8$ & 17.0 & $24.2 \pm 3.1$ \\
\hline ACEI $(n=15,184)$ & $66.5 \pm 11.3$ & 45.5 & $140.7 \pm 19.0$ & $85.6 \pm 11.0$ & 11.4 & $24.1 \pm 3.2$ \\
\hline $\operatorname{ARB}(n=1,492)$ & $66.8 \pm 10.8$ & 41.4 & $136.4 \pm|7|$. & $83.3 \pm 17.3$ & 17.3 & $24.8 \pm 3.2$ \\
\hline SI $(n=5,673)$ & $67.6 \pm 11.1$ & 47.7 & $139.8 \pm 17.8$ & $85.2 \pm 10.4$ & 12.0 & $24.2 \pm 3.4$ \\
\hline $\mathrm{Cl}(\mathrm{n}=4,05 \mathrm{I})$ & $66.2 \pm 11.0$ & 48.4 & $143.5 \pm 20.9$ & $86.6 \pm 12.3$ & 15.4 & $24.9 \pm 3.4$ \\
\hline$S 2(n=24,808)$ & $67.9 \pm 11.1$ & 41.1 & $140.7 \pm \mid 8.5$ & $85.5 \pm 10.6$ & 10.2 & $24.1 \pm 3.3$ \\
\hline Total $(n=81,777)$ & $67.2 \pm 11.0$ & 43.8 & $139.0 \pm 18.8$ & $84.5 \pm 10.9$ & 11.7 & $24.1 \pm 3.2$ \\
\hline
\end{tabular}

Notes: SI, fixed-dose single-pill combinations only including first-line drugs; S2, single-pill combinations including both first-line and non-first-line drugs; CI, multiple-pill combination of first-line drugs.

Abbreviations: ACEl, angiotensin-converting enzyme inhibitors; ARB, angiotensin receptor blockers; BB, beta-blocker; BMI; body mass index; CCB, calcium channel antagonist; DBP, diastolic blood pressure; D, diuretic; SBP, systolic blood pressure. 


\section{Publish your work in this journal}

Clinical Epidemiology is an international, peer-reviewed, open access, online journal focusing on disease and drug epidemiology, identification of risk factors and screening procedures to develop optimal preventative initiatives and programs. Specific topics include: diagnosis, prognosis, treatment, screening, prevention, risk factor modification,

Submit your manuscript here: https://www.dovepress.com/clinical-epidemiology-journa systematic reviews, risk and safety of medical interventions, epidemiology and biostatistical methods, and evaluation of guidelines, translational medicine, health policies and economic evaluations. The manuscript management system is completely online and includes a very quick and fair peer-review system, which is all easy to use. 